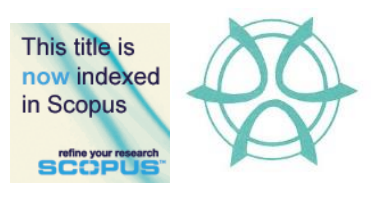

PLANNING MALAYSIA:

Journal of the Malaysian Institute of Planners

VOLUME 16 ISSUE 1 (2018), Page 222 - 230

\title{
MEASURING THE SWAY OF IMPERCEPTIBLE FACTORS IN SHAPING THE DISTINCT CHARACTER OF ANCIENT INDIAN ARCHITECTURE AND CITY PLANNING
}

\author{
Tamara Kelly ${ }^{1}$ \\ ${ }^{1}$ School of Engineering \\ ABU DHABI UNIVERSITY, UNITED ARAB EMIRATES
}

\begin{abstract}
In India, great obey to nature is evident in architecture, and the essence of life is fairly apparent in city planning. Human kind reflects his perception of life in architecture by locating the spaces within the dwelling in particular order to ensure great harmony with positive and negative forces of the cosmos. Modern architecture shaped by political and economic factors resulted in sameness among most of contemporary capitals or developments, ignoring farming and human needs that has caused decays in urban fabric, and resulting in high level of gas emissions in mega cities. By contrast, ancient architecture in India connects the occupants with surrounding environment and ensure harmony between humans and nature through many aspects, and scale is a great element being considered in space and city planning leading into the Mandala graph. In Indian philosophy, disproportion and detachment of mankind from nature and surrounding environment lead to disaster. Hence, the Mandala diagram addresses all the existence taking into account farming, human scale and needs. The purpose of this research is to examine the impact of intangible factors such as traditional beliefs and religions in shaping the astonishing character of Indian architecture. Furthermore, it delves ino many metaphysic theories to test their influences on evolving the Mandala diagram and the logic behind the distribution of functions within its parts.
\end{abstract}

Keyword: Mandala diagram, Vastu Purusha, five elements, the Vedika, responsive architecture 
PLANNING MALAYSIA

Journal of the Malaysia Institute of Planners (2018)

\section{INTRODUCTION}

Every remarkable architecture reflects great conception and principles. The Greek conveyed their interests in literature and art through constructing marvel theatres and discerning architecture. While the Romans echoed their many achievements in sciences through establishing advanced water supply ducts and heating systems in public baths. Sewage systems were available in their cities and the invention of concrete led to vast spans in Italy. In Europe, great churches initiated glorifying and symbolized the dominance of religion authority, in the same way the Indian architecture progressed but with different influences. This research is an attempt to help students and researchers to understand how Indian philosophers provided different approaches in architecture by acknowledging other intangible forces such as divine forces and evil motivates.

Nowadays cities are similar, with buildings and skyscrapers in Dubai, Singapore and Kuala Lumpur are alike, and plants, trees or finishing materials may only look different in contemporary capitals. Mega cities diminish human peace and generated many problems for societies, such as traffic jam, pollutions and high level of crime. Harmony between individuals has also vanished.

Whereas ancient cities recognized human scale and sustainability where all building materials were local and settlements were safer with great harmony between settlers. Indian cities meet most of their resident's needs and addresses social cultural customs. The character of the blocks are different in Indian towns, but premises are in great harmony and the atmosphere is positive as villagers interact with each other. Moreover, everything can be reached within short distances.

In India many philosophies inspired scientists thinking and led to form distinct norms, among which is the appreciation of nature. Indian architects believe that nature is a crucial factor and affects mankind in various ways. It can influence us internally - spiritually and psychology, or externally -physically. Likewise, mankind shares the earth with many other existence including animals, plants and different forces that affect his cognizance. Hence, Indian architecture reflects every aspect of our universe. Evil and divine forces are also acknowledged, and consequently spaces in Indian premises are distributed in harmony with those forces to maintain positive level of energy. "As human body is a combination of divine and evil forces, a site is also a combination of divine and demonic forces" (Bubbar, 2005, p.25). This conception has led to numerous Mandala graphs, which are celestial diagrams addressing all existence and divided into sections representing various aspects including evil, godly forces, plants and animals. Mandala graphs are commonly used as guidance to locate spaces or buildings within the site according to specific logic, for instance kitchen is located in fire section in Mandala, and a farming or furnaces can be placed near god of sun Isha (Figure 1). Religion is another crucial contributor in shaping the 
Tamara Kelly

Measuring the Sway of Imperceptible Factors in Shaping the Distinct Character of Ancient Indian Architecture and City Planning

architecture of India, every aspect of life is controlled by various deities guiding rain, wealth, death justice, sun, moon and youth.

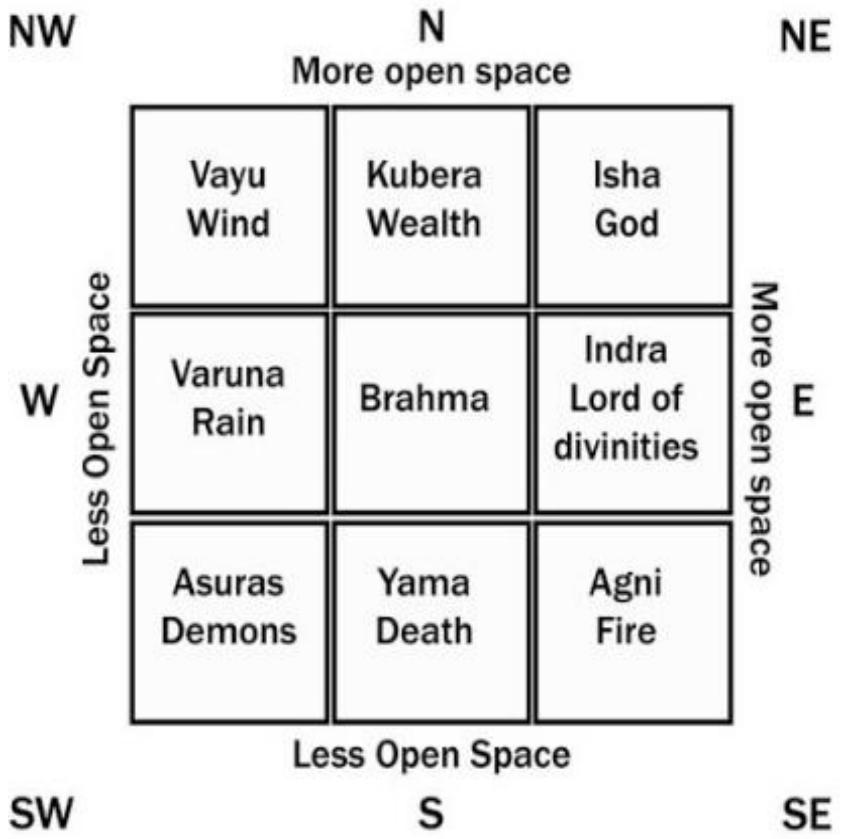

Figure 1: Location of gods in Indian Mandala graph

Most of goddesses are represented in Mandala graph and impact the setting of spaces or premises in city planning. In fact, locations of divinities in Mandala is determined by sun motion since it rises from east. Aditya god of sun, brightness, power and warmth divine forces are located in east quarter. Therefore, functions relevant to administration and power are usually located eastwards. The west is sun setting direction, which is cold and represent oceanic rainy side where Varuna god of water is situated in Mandala. Northwards is the arctic coolness, distant from sun path and associated with moon. North is also the place of Soma lord of wealth, moon, or light but cold light contradicting the warm rays of sun light. Hence, financial activities are positioned in this section. Whereas south is warm as sun voyages in this path therefore god of fire Agni is in southern quarter. Thus, Mandala's layout reflects the influence of religion, where each aspect of life is controlled by specific God and it is apparent locations of the goodness in Mandala related to sun path and the four cardinals. "The Mandala distinguishes the areas belonging to cosmic forces - good and bad. The planner propitiates the forces needed for the project. The east is the rising of the sun, brightness in character. The west is ocean / water or setting of sun; the north is ascribed to the moon, cooler in character and the south is assigned to heat, warmer in character. " (Bubbar, 2005, p43). 
PLANNING MALAYSIA

Journal of the Malaysia Institute of Planners (2018)

\section{MANDALA GRAPH AND DISTRIBUTION OF FUNCTIONS}

Mandala shapes are numerous, but square Mandala or rectangle are very common in usage, while triangle is rarely used and circular ones are common in worshipping or buildings with divine purpose. Hexagon, octagonal or sixteen sided shapes Mandala also exist but uncommon.

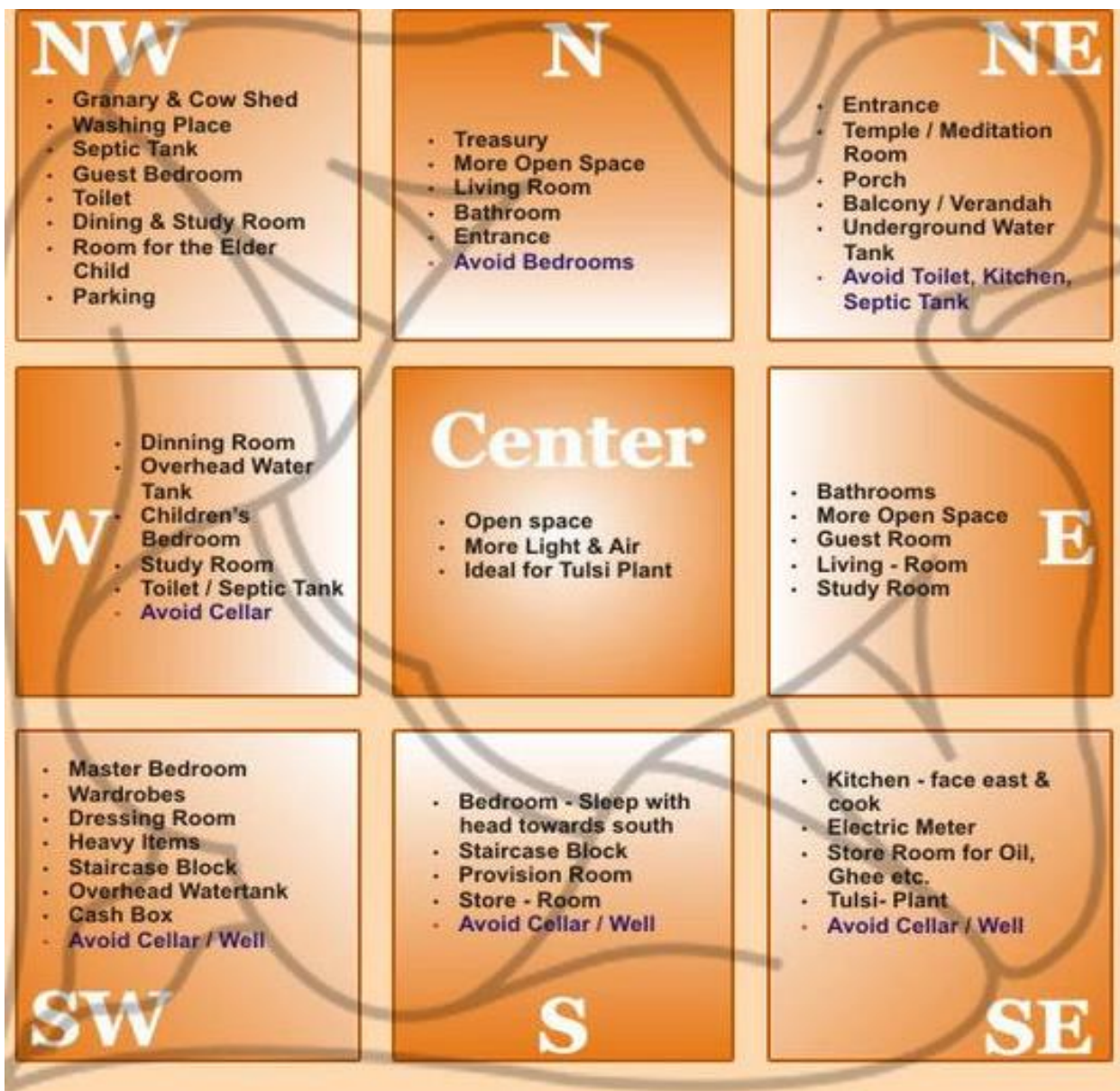

Figure 2: Ideal placement of spaces

There are 32 types of Mandala exist in India and many features are shared between them. For instance, on the east side of the graph is Adita or Isha god of sun, it is a divine force and commonly host worshiping activities, farming, orchids and dairy. Southern side is Yama the god of death and in command of justice and rules the death orders. It is regarded as divine demonic force, hence courts, jails, butchery, brothels and burial ground situated in this area. Western side is Varuna god of water or ocean, which is a celestial force and lodge traveling trading 
Tamara Kelly

Measuring the Sway of Imperceptible Factors in Shaping the Distinct Character of Ancient Indian Architecture and City Planning

activities, treasury, industry and defences academics. Finally, Soma the moon is in northern side and the central part is dedicated to goddess of earth and open to sky. There are Mandalas for site planning and also for dwellings. For instance, Pitha is simplest and the first sample consists of $3 \times 3$ sections with core open to sky and other parts are dedicated to divine forces such as fire, water, wind, ancestress, justice or death god. This basic diagram is suitable for domestic and public buildings. Furthermore, its layout was inspiration for other sophisticated Mandalas. "The planning system, through the Mandala, takes into account the five basic elements of creation space, Air, Fire, Water, Earth and also the inherent of divine and demonic forces." (Bubbar, 2005, p37).

In fact, any site is an amalgam of positive and negative aspects. Hence, Indian architects developed the Mandala to deal with such opposite forces and consequently the layout of the buildings reflect ecological forces and other balances. The five-element theory of life, air, fire, water and earth are recognized in Mandala layout and occupy the corners (Figure 2). For instance the northwest corner indicated Vayavya - air force symbolizing movement. Hence, it is preferable that transit activities are located in this area such as guest room, unmarried person room or a finished material storage where the items are subject to movement or delivery shortly. "The northwest corner of Vayavya is represented by air and guarded by Paparakahashi. This is characterized by its movement. Therefore, it is ideal to place transit activities in this area" (Bubbar, 2005, p41). Vayu is lord of wind and located adjacent to god of air. It represents divine forces, thus northwest quarter commonly occupied by activities that reflect law enforcement, distilleries and professional. Northeast corner dedicated to Isha god of sun and for locating worshiping spaces or buildings. Southeast corner represents Agneya - fire and commonly a kitchen, boiler room or bread furnace shop is ideal to be located here. "The southeast corner or Angenya represent Angi- the fire and guarded by Vidari. It is characterises heat. Therefore, it is the ideal location for the kitchen" (Bubbar, 2005, p41). The west south spot where Nairutya - earth force exists, and commonly physical functions such as massage room, dining or dressing, maternity room, hospital, jail or slaughter room are common in this area. Worshipping and ancestor's deity take place in two different sections, southwest or northeast corners. This variety allows the designer flexibility to locate the spaces according to site condition. "The northeast corner or Isan is represented by water and is guarded by Charki. This corner of Isan is recommended as a place of worship" (Bubbar, 2005, $\mathrm{p} 41)$. Even the location of main entrance is determined by reference to specific theory. The door can be in one of the four directions, north, east, south or west. If the door is placing in north, it underscores the intellectual aspect and east for administrative while west for business and south for workers. 
PLANNING MALAYSIA

Journal of the Malaysia Institute of Planners (2018)

\section{POSTURE OF VASTU PURUSH MODEL}

As mentioned earlier the Mandala takes into account the five elements; life, fire, water, earth, wind, as well plants, animals, ancestors, demonic and divine forces. These elements should be balanced within the dwellings to enhance the flow of energy and consequently the occupant's health. Nature is in the core of Indian architecture. In various ways it influences dwellings layout and represented by a figure known as Vastu Purusha set within the Mandala graph. According to this notion, the torso of the figure is in the middle of the diagram and should be free from pain. Thus, the centre of dwelling should be free from columns and open to sky. "Nature, the governing power of the cosmic processes in the universe, is omnipresent. Nature govern every piece of land and every dwelling. The scriptures refer to this as the presiding spirit. This spirit, in architectural parlance, is called the Vastu Purusha." (Bubbar, 2005, p37). Location of courtyard is commonly in the middle, but it can also occupies the corners or the sides. The courtyard accommodates Vedika (sacrificial alter) for worshiping and family gathering or celebrating events. "While designing, due care must be taken to ensure that the nerve centers or the vulnerable points of the Purusha are not put to pain therefore structural members like columns, walls, fire places or anything that can cause pain to the Vasta Purusha must be avoided." (Bubbar, 2005, p39). Another crucial idea is the offering or oblation to fire which normally occurs in the courtyard. Fire maintains good eyesight and is life giving energy similar to sun that should not be extinguished or wane. Later, the Vedika replaced by basil leaf or different types of medical plants, which can be used to heal diseases. The beauty of nature apparent in mountains, flowing water features and frosts may not be available in every site, hence the courtyard compensates deficiencies of natural features and commonly accommodates plants and water elements. In fact, having an open space for gathering is replicated in city planning in ancient Indian cities. Settlements commonly accommodate numerous open zones woven within every district, allowing people from same background to socialize (Figure 3). 
Tamara Kelly

Measuring the Sway of Imperceptible Factors in Shaping the Distinct Character of Ancient Indian Architecture and City Planning

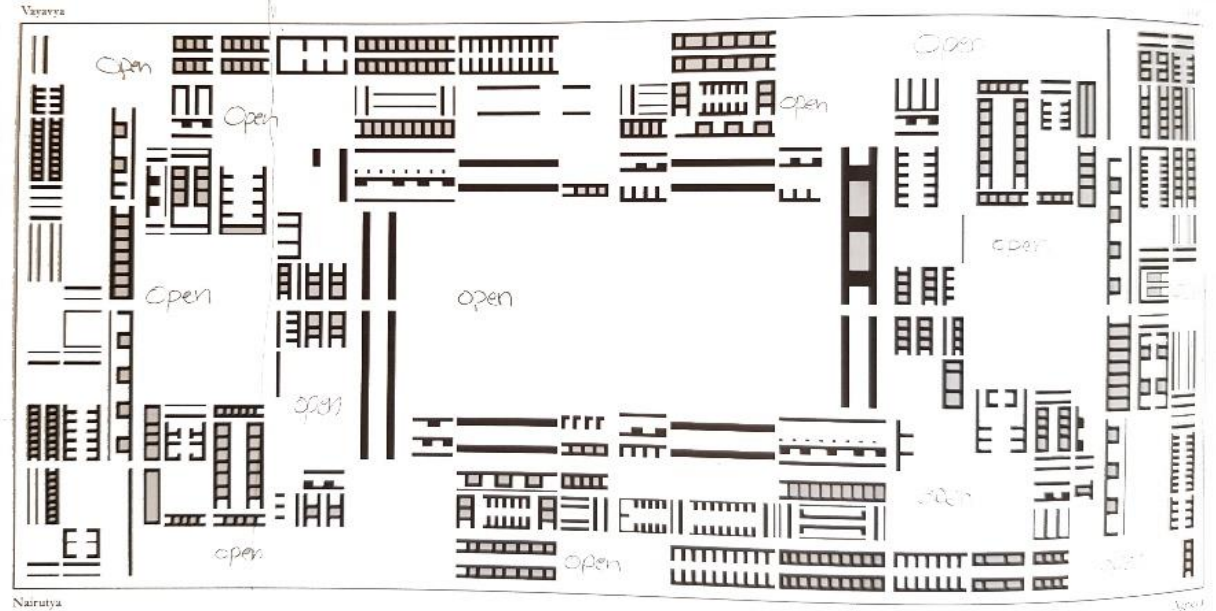

Figure 3: Open areas woven within the urban fabric

Likewise, settlements in India were shaped by particular rationality. Indian philosophers think that every society is usually divided into four sectors. The first one represents thinkers or planers who undertake the intellectual work and called Brahmin Cuna. They assist in maintaining the literary culture of society and when the intellectual falls it will lead to corruption and the nation will ruin. Second sector is in charge of administration and governing mission. Therefore, they are the politicians or rulers known as Kashatriya Guna. The third sector is the Vaishya Guna, which consists of traders and farmers. The final one consists of the Shudra Guna - the labourers and blue-collar workers who assist the other three sectors (Figure 4).

Ancient Indians were against admixture. They believed it would mess up the values in society and caused adverse progeny and create deep psychological tensions. People of same rank should live together and admixture can cause fear among settlers For instance, mother of children would not feel safe letting her children socialize and play with other youngsters coming from different caste. Hence, segregating is evident in Indian city planning and reflects social culture.

Ancient nations were aware of energy level radiating from earth and planned their buildings to benefit from positive energy. In China, proposed location of any settlement were investigated carefully by the ruler's officers and commonly cities were built at foot of mountains and nearby water body or frost to benefit from the energy radiating from natural landscape. Greeks took into consideration the earth energy field and designed their city Agors to benefit from such energy and similarly the ancient Greek urban planner Hippodamus of Miletus known by his methodology of using the grid iron patterns in city planning. The spaces within the grid lines are in the positive energy, therefore 
PLANNING MALAYSIA

Journal of the Malaysia Institute of Planners (2018)

suitable for blocks. Whereas, the intersections of grids lines are within the negative or low energy of earth and human activities are not placed in the nodes.

Every object radiates energy and the Lecher Antenna can be used to measure the radiation of energy and also the gems have powerful effect on energy level of humans. Similarly, the Mandala lowers the effect of negative energy of existing site and create or accentuate positive energy level. Therefore, the Mandala was a key factor in city planning or designing the buildings internally and externally. In fact, Bubbar (2005) stated that an experiment that took place in a flat located in Mumbai revealed how a geobiological test carried out in the flat in certain zone showed certain elements can reverse the negative energy to positive energy. According to high level of negative energy, then a conch cell was placed in the area and the test was repeated. Surprisingly the reading showed positive energy level. The same was repeated but with a lit lamp and gave the same outcome and in particular when the lamp was located in Northern corner Isan, the negative energy changed to positive. Therefore, the conch shell and lamp are fundamental elements in worshiping in India. The flame can diminish negative energy and turn it into positive.

In general, there are many graphs employed to design Indian settlements. However, the city is preferable to be established near water body, mountain or frost to utilize the energy coming from natural terrain. There are common features shared between those various Mandalas. The city should follow grid layouts, roads are perpendicular and the core of the city is open to sky for public, temples commonly in northeast in Isan corner, many open areas are accommodated as a public meeting points and matching ranked citizens gathered in certain zones. 
Tamara Kelly

Measuring the Sway of Imperceptible Factors in Shaping the Distinct Character of Ancient Indian Architecture and City Planning

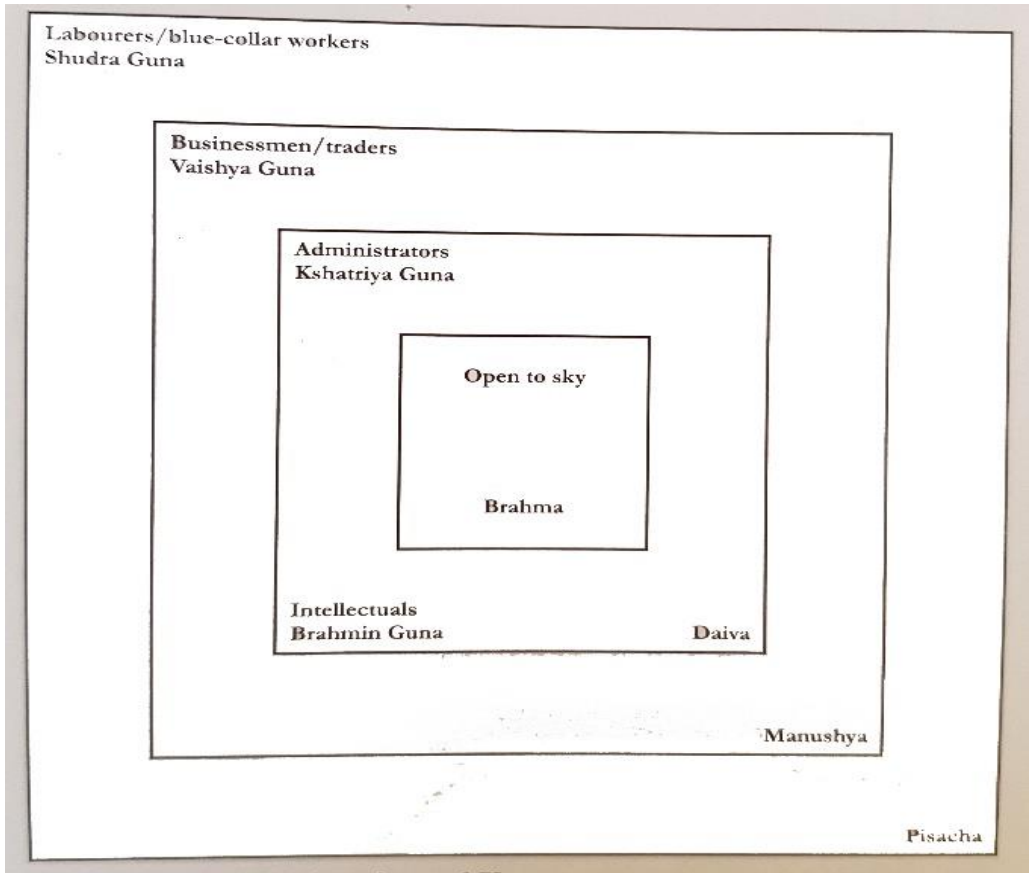

Figure 4: The divisions of Indian Society

\section{CONCLUSION}

The ancient Indian architecture is an amalgam of religion and traditional interpretations of how the decrees of nature affect mankind. Indian architects developed the Mandala graph which recognizes the principle of five elements. Within its components, the five elements are distributed according to sun path four cardinals or location of India on the planet earth. Among many planets in our galaxy, earth is the only sphere consists of these primary elements which are necessary to establish life. Thus, they are dominant in Mandala layout. Indian architects believe that the environment and occupant's wellbeing in any building or settlement can be enhanced by distributing the functions with great acknowledgment to divine and even evil forces. The acknowledgment of Indian norms and beliefs led into such distinct architecture which lasted since thousands of years and can be great inspiration for the coming generation. Furthermore, reviving our ancestor approach is a great tool to diminish similitude layout of nowadays capitals and creating long lasting architecture that never fade away over centuries.

\section{REFERENCES}

Bubbar, D. K. (2005). The spirit of Indian architecture. New Delhi: Rupa \&Company. 